\title{
Proses Metakognitif dalam Pengajuan Masalah Geometri Berdasarkan Gaya Kognitif Field Dependent dan Field Independent
}

\author{
Yuli Suhandono \\ Jurusan Pendidikan Matematika, Universitas Negeri Surabaya
}

\begin{abstract}
This study aimed to describe about metacognitive process of student in geometry problem posing based cognitive style Field Dependent (FD) and Field Independent (FI). The subjects were four students of grade X. The result showed that metacognitive process of subjects FD and FI first category in posing geometry problem, doing activity of planning, monitoring and evaluating process and the result thinking about every step of problem posing. Metacognitive process of subject FD of second category in posing geometry problem, doing activity of planning, monitoring, and evaluating process and the result thinking about step understanding information, arranging the planning of problem posing and formulating problem. Furthermore, metacognitive process of subject FI second category in posing geometry problem, doing of planning activity, monitoring and evaluating process and the result thinking about step understanding information, arranging the planning of problem posing and controlling back of suitability problem made with first information.
\end{abstract}

Keywords: Metacognitive process; Problem posing; Cognitive style.

\section{PENDAHULUAN}

Geometri merupakan bagian dari matematika yang erat kaitannya dengan masalah yang ada dalam kehidupan sehari-hari. Beberapa tujuan belajar geometri adalah mengembangkan kemampuan berpikir logis, menanamkan pengetahuan untuk menunjang materi yang lain dan mampu membangun argumen-argumen matematika mengenai hubungan geometri dengan lainnya (Budiarto, 2000; National Council of Teachers of Mathematics (NCTM), 2007). Seharusnya geometri lebih mudah dipahami oleh siswa dibandingkan cabang matematika lain. Namun, kenyataannya masih banyak siswa yang mengalami kesulitan dalam memecahkan masalah geometri di tingkat sekolah menengah. Misalnya penelitian Abdussakir (2009) menunjukkan hasil tes geometri siswa SMA kurang memuaskan dibandingkan dengan materi matematika yang lain.

Lemahnya kemampuan geometri siswa SMA, salah satunya disebabkan oleh lemahnya kemampuan mereka dalam pemecahan masalah. Resnick (1987) mengungkapkan bahwa untuk meningkatkan kemampuan pemecahan masalah, siswa dapat dilatih dengan cara memberikan stimulus kepada mereka dalam menganalisis 
masalah, membuat pertanyaan dan memprediksi situasi yang diberikan. Kemampuan ini berkorelasi dengan kemampuan pengajuan masalah. Cai, Lane, \& Jakabcsin (1996) menyatakan kemampuan siswa sekolah menengah dalam pengajuan masalah mempunyai hubungan yang kuat dan positif dengan kemampuan pemecahan masalah. Sedangkan Siswono (2002) menyatakan ketika seorang siswa dapat mengajukan masalah dengan baik maka baik pula dalam menyelesaikan suatu masalah. Oleh sebab itu siswa akan termotivasi dalam pemecahan masalah jika telah mengajukan masalah berdasarkan kebutuhan dan kesadaran mereka sendiri.

Seorang guru perlu mempertimbangkan banyak hal dalam memilih strategi untuk mengajarkan suatu materi kepada siswa khususnya dalam pemecahan masalah. Arends (1997) menyatakan bahwa mengajarkan suatu materi yang baik kepada siswa tidak hanya men-transfer knowledge saja, tetapi juga mengajarkan bagaimana belajar, bagaimana mengingat, bagaimana berpikir, dan bagaimana memotivasi diri sendiri. Salah satu aktivitas mengajarkan bagaimana berpikir tentang berpikirnya sendiri disebut sebagai metakognisi (Flavell, 1976). North Central Regional Educational Laboratory (1995) mengemukakan tiga hal dasar dalam metakognisi yaitu mengembangkan rencana tindakan, memonitor rencana tindakan dan mengevaluasi rencana tindakan.

Pemanfaatan metakognitif siswa dalam pembelajaran akan dipengaruhi oleh karakteristik atau gaya kognitif siswa yang berbeda-beda. Gaya kognitif menurut Witkin, Moore, Goodenough, \& Cox (1977) terbagi menjadi dua macam, yakni field dependent (FD) dan field independent (FI). Individu yang memiliki gaya kognitif FD adalah individu yang bersifat global yang memfokuskan pada lingkungan secara keseluruhan, didominasi atau dipengaruhi lingkungan. Individu yang memiliki gaya kognitif FI adalah individu yang bersifat analitik yang merasakan lingkungan ke dalam komponen-komponen yang ada pada dirinya, kurang bergantung pada lingkungan, atau kurang dipengaruhi oleh lingkungan.

Komponen utama pada metakognitif terdiri dari dua yaitu pengetahuan metakognitif dan strategi metakognitif (Frenkel, 2014). Pengetahuan metakognitif didefinisikan sebagai bagian dari pengetahuan terkait dunia yang memiliki hubungan dengan individu sebagai makhluk kognitif dengan berbagai tujuan, tugas, tindakan dan pengalaman kognitif mereka (Flavel, 1979). Adapun komponen pengetahuan metakognitif dibagi lagi menjadi jenis pengetahuan (apa yang kamu ketahui), jenis 
prosedural (apa yang kamu pikirkan), atau jenis kondisional (kapan dan mengapa kamu menerapkan pengetahuan dan strategi tersebut).

Strategi metakognitif didefinisikan kegiatan yang digunakan untuk mengatur dan mengawasi pembelajaran (Brown, 1987). Frenkel (2014) menyebutkan bahwa komponen dari strategi metakognitif dibagi menjadi 3 yaitu planing atau merencanakan aktivitas (prediksi hasil, menjadwalkan strategi dan lain-lain), monitoring atau memantau aktivitas (monitoring, pengujian, revisi dan menjadwalkan ulang strategi untuk pembelajaran), dan mengevaluasi hasil (evaluasi hasil dari setiap tindakan strategi yang dibandingkan dengan kriteria yang efisien).

Siswono (2002) dan Desoete menyebutkan bahwa komponen dari planning terdiri dari 5 indikator (Sudia, 2013), yaitu: (1) sadar terhadap proses dan hasil berpikirnya, dalam merencanakan apa yang akan dilakukan untuk memahami informasi, (2) sadar terhadap proses dan hasil berpikirnya, dalam merencanakan hal yang akan dilakukan untuk menyusun rencana dalam pengajuan masalah, (3) sadar terhadap proses dan hasil berpikirnya, dalam merencanakan hal yang akan dilakukan untuk merumuskan masalah dengan memikirkan akan menggunakan susunan kalimat seperti apa pada penulisan masalah yang dibuat, (4) sadar terhadap proses dan hasil berpikirnya, dalam merencanakan untuk menggunakan rencana yang telah dibuat untuk menyelesaikan masalahnya, dan (5) sadar terhadap proses dan hasil berpikirnya, dalam merencanakan saat akan memeriksa kembali masalah yang dibuat.

Komponen dari monitoring terdiri dari 5 indikator, yaitu: (1) sadar terhadap proses dan hasil berpikirnya, dalam memantau langkah yang dilakukan dalam memahami informasi, (2) sadar terhadap proses dan hasil berpikirnya, dalam merencanakan hal yang akan dilakukan untuk menyusun rencana dalam pengajuan masalah, (3) sadar terhadap proses dan hasil berpikirnya, dalam memantau hal yang dilakukan dalam merumuskan masalah, (4) sadar terhadap proses dan hasil berpikirnya, dalam memantau penggunaan rencana penyelesaian yang telah dibuat untuk menyelesaikan masalahnya, dan (5) sadar terhadap proses dan hasil berpikirnya, dalam memantau pemeriksaan kembali masalah yang dibuat.

Komponen dari evaluasi terdiri dari 5 indikator, yaitu: (1) sadar terhadap proses dan hasil berpikirnya, dalam mengevaluasi langkah yang digunakan dalam memahami informasi, (2) sadar terhadap proses dan hasil berpikirnya, dalam mengevaluasi hal yang 
dilakukan dalam menyusun rencana pengajuan masalah, (3) sadar terhadap proses dan hasil berpikirnya, dalam mengevaluasi hal yang dilakukan dalam merumuskan masalah, (4) sadar terhadap proses dan hasil berpikirnya, dalam mengevaluasi kebenaran penggunaan langkah dan hasil penyelesaian apakah telah sesuai rencana atau belum, dan (5) sadar terhadap proses dan hasil berpikirnya, dalam mengevaluasi pemeriksaan kembali masalah yang dibuat.

Adapun penelitian yang berhubungan dengan metakognisi maupun pengajuan masalah yang telah dilakukan oleh Yeap (1997), Desoete (2007), Dawson \& Fucher (2008), Kuzle (2011), Sudia (2013), dan Karnain, Bakar, Siamakani, Mohammadikia, \& Candra (2014). Hal ini mendorong peneliti untuk mendeskripsikan proses metakognitif siswa dalam hal merencanakan proses berpikirnya, memantau proses berpikirnya serta mengevaluasi proses dan hasil berpikirnya dalam pengajuan masalah geometri berdasarkan gaya kognitif FD dan FI yang dirasa peneliti masih belum banyak dilakukan oleh peneliti lain.

\section{METODE PENELITIAN}

Jenis penelitian ini adalah deskriptif kualitatif yang bertujuan untuk mendeskripsikan proses metakognitif siswa SMA dalam pengajuan masalah geometri berdasarkan gaya kognitif field dependent (FD) dan field independent (FI). Adapun kategori siswa dalam pengajuan masalah disajikan pada Tabel 1.

Tabel 1.

Kategori Siswa dalam Pengajuan Masalah

\begin{tabular}{|c|c|c|c|c|c|}
\hline & \multirow{2}{*}{ Kategori Siswa dalam Melaksanakan TPMG1 } & \multicolumn{2}{|c|}{ Kode Siswa } & \multicolumn{2}{|c|}{ Jumlah } \\
\hline & & FD & FI & FD & FI \\
\hline K1 & $\begin{array}{l}\text { 1.1 Siswa dapat menyelesaikan masalah awal dengan benar } \\
\text { 1.2 Siswa dapat membuat masalah dengan benar } \\
\text { 1.3 Siswa mampu menyelesaikan masalah yang dibuat } \\
\text { dengan benar }\end{array}$ & SD1 & SI1 & 1 & 4 \\
\hline K2 & $\begin{array}{l}\text { 2.1 Siswa dapat menyelesaikan masalah awal dengan benar } \\
\text { 2.2 Siswa dapat membuat masalah dengan benar } \\
\text { 2.3 Siswa tidak mampu menyelesaikan masalah yang dibuat }\end{array}$ & SD2 & SI2 & 5 & 4 \\
\hline K3 & $\begin{array}{l}\text { 3.1 Siswa dapat menyelesaikan masalah awal dengan benar } \\
\text { 3.2 Siswa tidak dapat membuat masalah }\end{array}$ & SD3 & SI3 & 0 & 0 \\
\hline K4 & $\begin{array}{l}\text { 4.1 Siswa tidak dapat menyelesaikan masalah awal } \\
\text { 4.2 Siswa dapat membuat masalah dengan benar } \\
\text { 4.3 Siswa mampu menyelesaikan masalah yang dibuat } \\
\text { dengan benar }\end{array}$ & SD4 & SI4 & 0 & 1 \\
\hline K5 & 5.1 Siswa tidak dapat menyelesaikan masalah awal & SD5 & SI5 & 15 & 2 \\
\hline
\end{tabular}




\section{Kategori Siswa dalam Melaksanakan TPMG1}

5.2 Siswa dapat membuat masalah dengan benar

5.3 Siswa tidak mampu menyelesaikan masalah yang dibuat

K6 6.1 Siswa tidak dapat menyelesaikan masalah awal 6.2 Siswa tidak dapat membuat masalah

Penelitian dilakukan di SMAN 3 Sidoarjo. Subjek penelitian sebanyak 39 siswa kelas X MIPA 2 yang terdiri dari 28 siswa bergaya kognitif FD dan 11 siswa bergaya kognitif FI. Instrumen penelitian ini terdiri dari tes gaya kognitif, tes pengajuan masalah geometri (TPMG) dan pedoman wawancara. Adapun tes pengajuan masalah disajikan pada Tabel 2.

Tabel 2.

Tes Pengajuan Masalah Geometri (TPMG)

\begin{tabular}{lll}
\hline \multicolumn{1}{c}{ Masalah 1 } & \multicolumn{1}{c}{ Perintah } \\
\hline Diketahui kubus ABCD.EFGH dengan & 1. & Selesaikan masalah tersebut! \\
panjang rusuk $6 \mathrm{~cm}$. Hitunglah jarak titik B ke & 2. & Berdasarkan masalah yang sudah kamu \\
bidang AFC! & selesaikan, buatlah masalah baru yang \\
& lebih rumit dari pada masalah awal dan \\
& selesaikan masalah tersebut! \\
\hline
\end{tabular}

Teknik pengumpulan data dalam penelitian ini adalah (1) memberikan TPMG pada subjek, (2) subjek melakukan think-aloud sebelum, pada saat, dan setelah mengajukan masalah serta saat diwawancarai, dan (3) melakukan perekaman secara audio maupun visual pada saat wawancara. Analisis data dilakukan dengan cara mereduksi data, penyajian data, dan penarikan kesimpulan (Sugiyono, 2011). Adapun inidikator proses metakognitif dalam pengajuan masalah seperti pada Tabel 3.

Tabel 3.

Indikator Proses Metakognitif dalam Pengajuan Masalah

\begin{tabular}{llc}
\hline $\begin{array}{c}\text { Tahapan Pengajuan } \\
\text { Masalah }\end{array}$ & \multicolumn{1}{c}{ Indikator Proses Metakognitif } & Kode \\
\hline Memahami & $\begin{array}{l}\text { Planning/Merencanakan } \\
\text { Informasi }\end{array}$ & Sadar terhadap proses dan hasil berpikirnya, dalam \\
& $\begin{array}{l}\text { merencanakan apa yang akan dilakukan untuk memahami } \\
\text { informasi dengan: }\end{array}$ & \\
& $\bullet$ & Memikirkan untuk dapat mengetahui apa yang diketahui \\
& & \\
& pada masalah awal & Memikirkan untuk dapat mengetahui apa yang \\
& ditanyakan pada masalah awal & \\
\hline
\end{tabular}




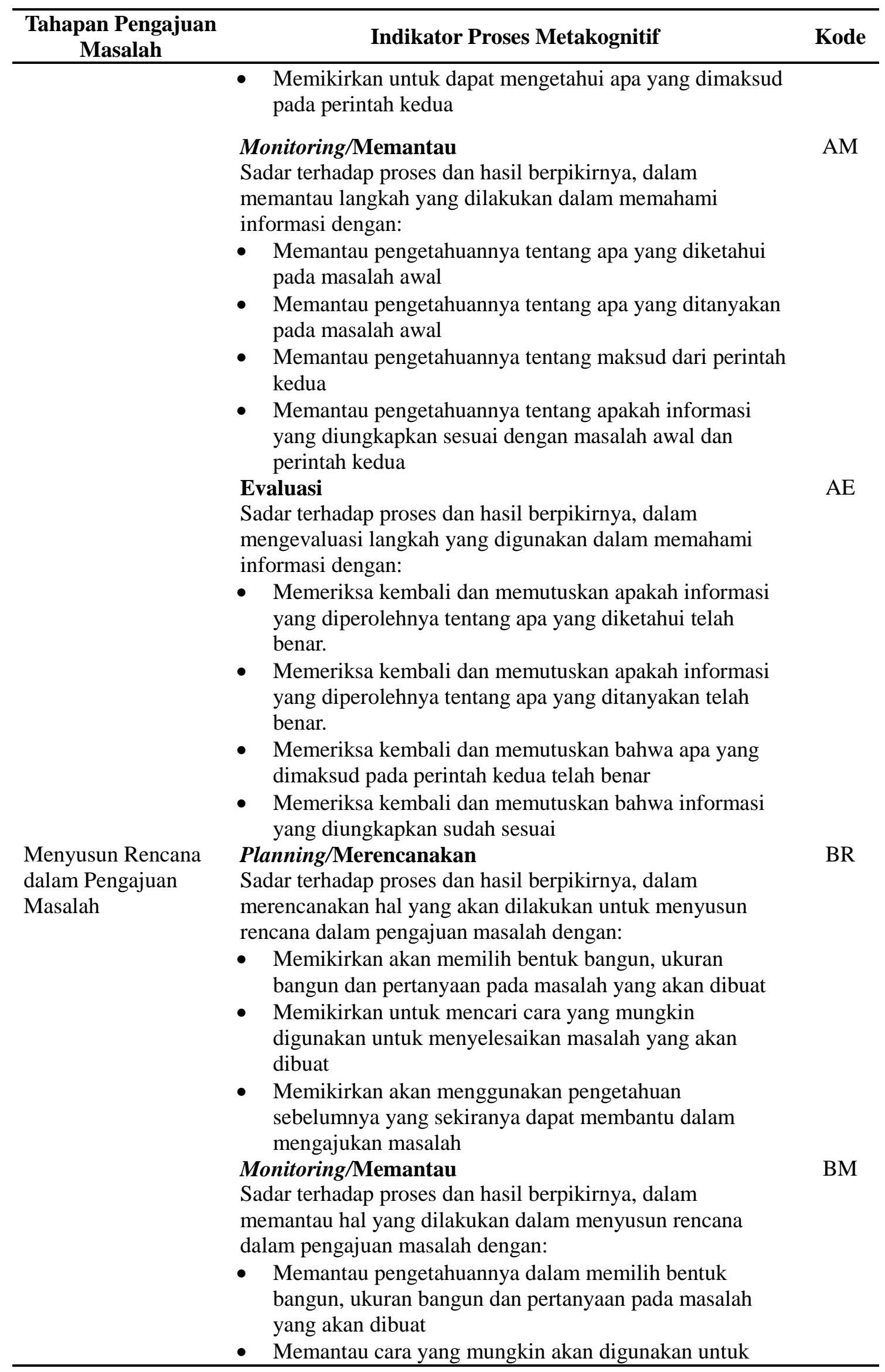




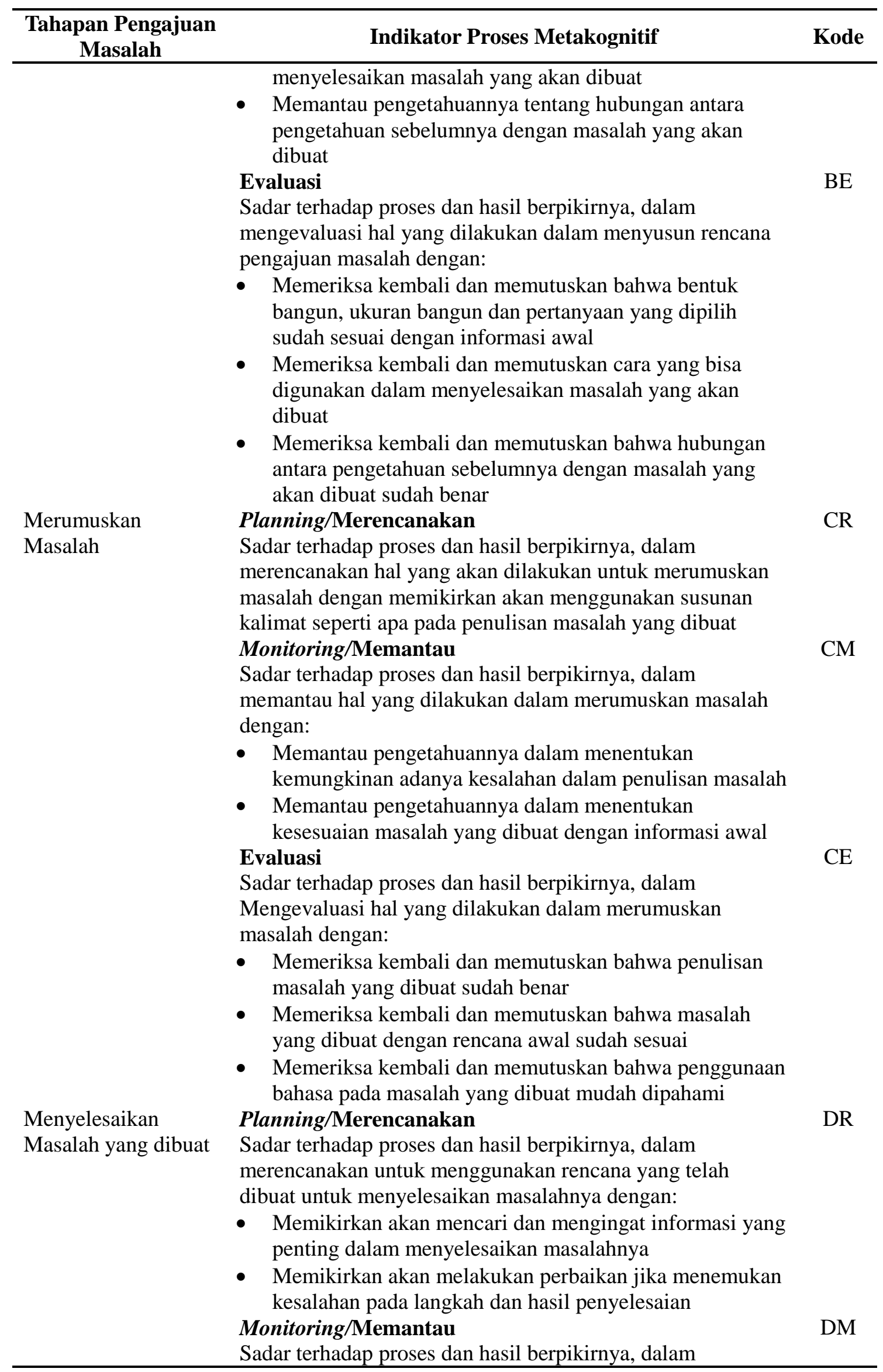




\begin{tabular}{|c|c|c|}
\hline $\begin{array}{c}\text { Tahapan Pengajuan } \\
\text { Masalah }\end{array}$ & Indikator Proses Metakognitif & Kode \\
\hline $\begin{array}{l}\text { Memeriksa Kembali } \\
\text { Masalah yang dibuat }\end{array}$ & $\begin{array}{l}\text { memantau penggunaan rencana penyelesaian yang telah } \\
\text { dibuat untuk menyelesaikan masalahnya dengan: } \\
\text { - Memantau informasi yang yang digunakan dalam } \\
\text { menyelesaikan masalahnya } \\
\text { - Memantau dan melaksanakan langkah perbaikan jika } \\
\text { menemukan kesalahan } \\
\text { Evaluasi } \\
\text { Sadar terhadap proses dan hasil berpikirnya, dalam } \\
\text { mengevaluasi kebenaran penggunaan langkah dan hasil } \\
\text { penyelesaian apakah telah sesuai rencana atau belum } \\
\text { dengan: } \\
\text { - Memeriksa dan memutuskan apakah informasi yang } \\
\text { digunakan benar } \\
\text { - Memeriksa dan memutuskan bahwa perbaikan yang } \\
\text { dilakukan telah sesuai dan mampu memperbaiki kesalahan } \\
\text { Planning/Merencanakan } \\
\text { Sadar terhadap proses dan hasil berpikirnya, dalam } \\
\text { merencanakan saat akan memeriksa kembali masalah yang } \\
\text { dibuat dengan: } \\
\text { - Memikirkan akan memeriksa apakah masalah yang } \\
\text { dibuat sesuai dengan informasi awal yang telah diperoleh } \\
\text { Memikirkan akan melakukan perbaikan jika terdapat } \\
\text { ketidaksesuaian masalah yang dibuat dengan informasi } \\
\text { awal } \\
\text { Monitoring/Memantau } \\
\text { Sadar terhadap proses dan hasil berpikirnya, dalam } \\
\text { memantau pemeriksaan kembali masalah yang dibuat } \\
\text { dengan: } \\
\text { - Memeriksa apakah masalah yang dibuat sesuai dengan } \\
\text { informasi awal } \\
\text { - Melakukan perbaikan jika terdapat ketidaksesuaian } \\
\text { masalah yang dibuat dengan informasi awal } \\
\text { Evaluasi } \\
\text { Sadar terhadap proses dan hasil berpikirnya, dalam } \\
\text { mengevaluasi pemeriksaan kembali masalah yang dibuat } \\
\text { dengan: } \\
\text { antara masalah yang dibuat dengan informasi awal } \\
\text { pemeriksa kembali dan memutuskan bahwa } \\
\text { sudah sesuai } \\
\text { - }\end{array}$ & EM \\
\hline
\end{tabular}

Diadaptasi dan modifikasi dari Siswono (2002) dan Desoete (Sudia, 2013)

\section{HASIL DAN PEMBAHASAN}

Subjek dalam penelitian ini dipilih berdasarkan hasil gabungan tes gaya kognitif (GEFT). Tes ini diadaptasi dari Witkin et al. (1977) dan berdasarkan kategori yang 
sesuai dengan pengajuan masalah tipe post-solution. Subjek tersebut yaitu subjek 1 (SDK1) adalah subjek yang berjenis kelamin laki-laki bergaya kognitif FD, subjek 2 (SDK2) berjenis kelamin perempuan bergaya kognitif FD, subjek 3 (SIK1) berjenis kelamin laki-laki bergaya kognitif FI, subjek 4 (SIK2) berjenis kelamin laki-laki bergaya kognitif FI. Selanjutnya, hasil karakteristik proses metakognitif subjek dalam pengajuan masalah geometri dipaparkan dengan mengacu pada setiap komponen indikator proses metakognitif yaitu merencanakan, memantau dan mengevaluasi.

\section{Proses Metakognitif Subjek 1 (SDK1)}

Pada subjek SDK1 dalam pengajuan masalah telah menunjukkan proses metakognitif pada aktivitas merencanakan, memantau dan mengevaluasi dalam setiap tahapan pengajuan masalah, yaitu AR, AM, AE, BR, BM, BE, CR, CM, CE, DR, DM, DE, ER, EM, dan EE. Alur proses metakognitif dalam pengajuan masalah pada setiap indikator seperti pada Gambar 1.

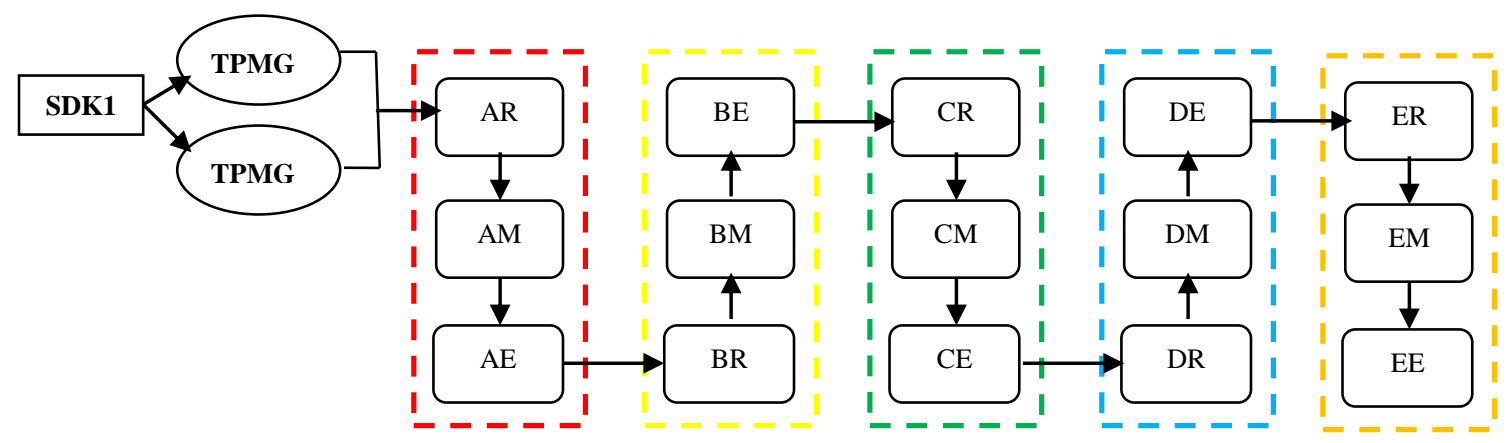

Gambar 1. Proses Metakognitif SDK1

Keterangan:

$\rightarrow:$ Arah Proses

[j: Tahap Memahami Informasi

: Tahap Menyusun Rencana

: Tahap Merumuskan Masalah

: Tahap Menyelesaikan Masalah yg dibuat

: Tahap Memeriksa Kembali Masalah yg dibuat

Pada saat memahami informasi, subjek melibatkan aktivitas metakognitif planning saat memikirkan cara memahami informasi dengan membaca perintah kedua dan mempelajari kembali masalah awal; melibatkan aktivitas metakognitif monitoring saat mengecek pemahaman informasi yaitu dengan mengungkapkan informasi yang dipahami pada perintah kedua, mengungkapkan informasi yang dipahami pada masalah awal, dan saat mengetahui adanya informasi lain yang dipahami pada masalah awal 
yaitu dengan cara memperhatikan kembali masalah awal; melibatkan aktivitas metakognitif evaluating saat memeriksa pemahaman informasi yaitu dilakukan dengan cara memperhatikan kembali perintah kedua dan masalah awal, saat memeriksa kesesuaian informasi yang diungkapkan dari yang dipahami pada perintah kedua maupun masalah awal dengan cara memperhatikan perintah kedua dan masalah awal.

Pada saat menyusun rencana pengajuan masalah, subjek melibatkan aktivitas metakognitif planning saat memikirkan bentuk bangun ruang, ukuran bangun dan pertanyaan pada masalah yang akan dibuat; melibatkan aktivitas metakognitif monitoring saat mengecek apa saja yang harus direncanakan sebelum menyusun masalah, yaitu dengan cara mengungkapkan bangun ruang, ukuran bangun ruang dan pertanyaan yang akan dipakai pada masalah yang akan dibuat dan saat mengecek ide asal dan alasan akan menggunakan ide tersebut, yaitu dengan cara mengungkapkan ide asal yang dipikirkan dan alasan memikirkan ide tersebut dalam menyusun rencana pengajuan masalah; melibatkan aktivitas metakognitif evaluating saat memeriksa kembali masalah yang sudah dipikirkan, yaitu dilakukan dengan cara membuat dan mengamati kembali oret-oretan ketika memeriksa tingkat kesulitan masalah yang akan dibuat, saat memeriksa kembali masalah yang sudah dipikirkan akan bisa diselesaikan, yaitu dengan menyatakan yakin bahwa masalah yang dipikirkan bisa diselesaikan; dan saat memeriksa kesesuaian rencana dalam menyusun masalah dengan informasi sebelumnya yang diperoleh, yaitu dilakukan dengan cara memperhatikan kembali masalah awal maupun perintah kedua.

Pada saat merumuskan masalah, subjek melibatkan aktivitas metakognitif planning saat memikirkan dan menuliskan masalah yang dipikirkan; melibatkan aktivitas metakognitif monitoring saat mengecek masalah yang dibuat ketika menyelidiki kebenaran apa yang ditulis dan saat menyelidiki apakah masalah yang dibuat mudah dipahami, yaitu dengan cara membaca kembali masalah yang dibuat; melibatkan aktivitas metakognitif evaluating saat menyelidiki kesesuaian pelaksanaan rencana dalam merumuskan masalah, yaitu dengan cara mengamati kembali masalah yang dibuat.

Pada saat menyelesaikan masalah, subjek melibatkan aktivitas metakognitif planning saat memikirkan untuk mencoba menyelesaikan masalah yang dibuat, saat memikirkan dan mengungkapkan langkah dan hasil akhir penyelesaian masalah yang 
dibuat; melibatkan aktivitas metakognitif monitoring saat menyelidiki kebenaran langkah dan hasil akhir penyelesaian masalah yang dibuat, yaitu dengan cara mengecek kembali langkah dan hasil akhir penyelesaian masalah yang dibuat; melibatkan aktivitas metakognitif evaluating saat menyelidiki kesesuaian pelaksanaan rencana dalam menyelesaikan masalah yang dibuat, yaitu dengan cara mengamati kembali apa yang sudah dikerjakan.

Pada saat memeriksa kembali, subjek melibatkan aktivitas metakognitif planning saat memikirkan untuk memeriksa kembali masalah yang dibuat, saat memikirkan dan mengungkapkan apa yang dipikirkan ketika memeriksa kembali kesesuaian masalah yang dibuat dengan informasi awal; melibatkan aktivitas metakognitif monitoring saat mengecek kembali masalah yang dibuat, perintah kedua dan masalah awal ketika menyelidiki kesesuaian masalah yang dibuat dengan informasi awal; melibatkan aktivitas metakognitif evaluating saat memperhatikan kembali masalah yang dibuat ketika meyakinkan pada diri sendiri bahwa masalah yang dibuat sudah sesuai dengan informasi awal; dan saat mengoreksi potensi diri sendiri dalam mengajukan masalah.

\section{Proses Metakognitif Subjek 2 (SDK2)}

Pada subjek SDK2 selama pengajuan masalah telah menunjukkan proses metakognitif pada aktivitas merencanakan, memantau dan mengevaluasi dalam tahapan pengajuan masalah. Namun, tidak melakukan proses metakognitif yang melibatkan aktivitas evaluasi pada tahap menyelesaikan masalah yang dibuat dan tidak melakukan proses metakognitif yang melibatkan aktivitas mengembangkan rencana dalam memeriksa kembali masalah yang dibuat yaitu AR, AM, AE, BR, BM, BE, CR, CM, CE, DR, DM, EM, dan EE. Alur proses metakognitif dalam pengajuan masalah pada setiap indikator seperti pada Gambar 2.

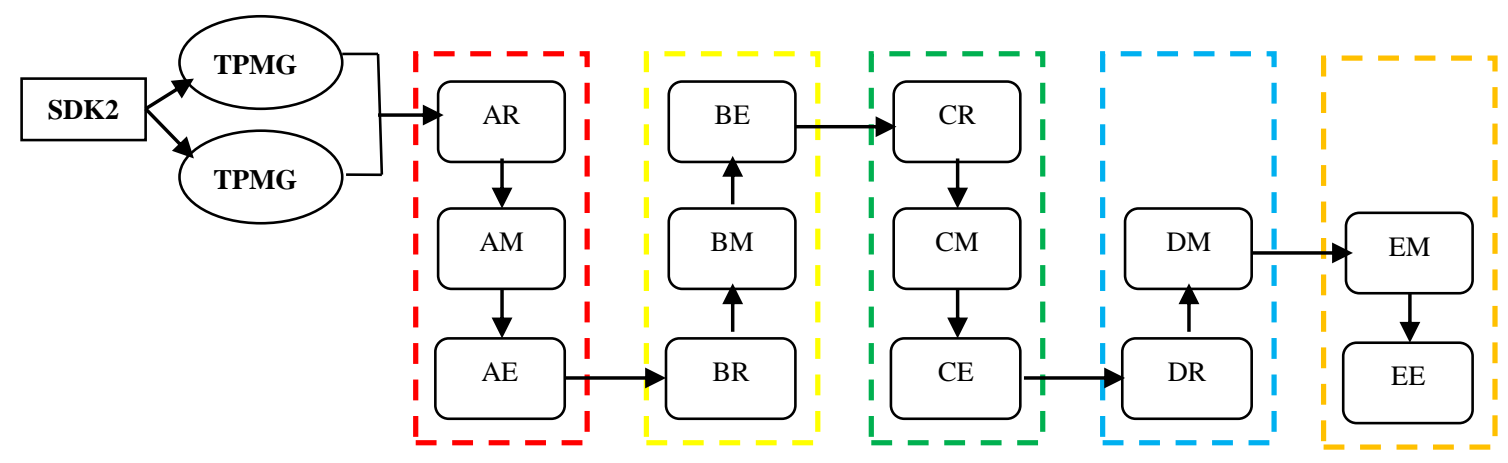

Gambar 2. Proses Metakognitif SDK2 
Pada saat memahami informasi, subjek melibatkan aktivitas metakognitif planning saat memikirkan memikirkan cara memahami informasi yaitu dengan cara membaca perintah kedua; melibatkan aktivitas metakognitif monitoring saat mengecek pemahaman informasi yaitu dengan cara mengungkapkan informasi yang dipahami pada perintah kedua; melibatkan aktivitas metakognitif evaluating saat memeriksa pemahaman informasi yaitu dilakukan dengan cara memperhatikan kembali perintah kedua; dan saat memeriksa kesesuaian informasi yang diungkapkan dari yang dipahami pada perintah kedua dengan cara memperhatikan perintah kedua.

Pada saat menyusun rencana pengajuan masalah, subjek melibatkan aktivitas metakognitif planning saat memikirkan dan mengungkapkan bangun ruang yang akan dipakai dan memikirkan juga ukuran bangun ruang pada masalah yang akan dibuat, saat mengungkapkan bahwa ada lagi rencana selanjutnya yaitu memikirkan dan mengungkapkan pertanyaan pada masalah yang akan dibuat dan saat mengungkapkan bahwa dia hanya memikirkan masalah yang lebih susah dari masalah sebelumnya tanpa memikirkan penyelesaiannya; melibatkan aktivitas metakognitif monitoring saat mengungkapkan ukuran bangun ruang yang akan dipakai pada masalah yang akan dibuat beserta alasan memilih ukuran tersebut, saat mengungkapkan ide asal yang dipikirkan dalam menyusun rencana pengajuan masalah dan saat mengecek adanya rencana lain selain yang diungkapkan dengan menyatakan tidak ada rencana lain selain yang sudah diungkapkan; melibatkan aktivitas metakognitif evaluating saat memeriksa tingkat kesulitan masalah yang akan dibuat yaitu, dengan cara memperhatikan oretoretan yang dibuat dan saat memeriksa kesesuaian rencana dalam menyusun masalah dengan informasi sebelumnya yang diperoleh, yaitu dengan cara memperhatikan kembali masalah awal dan perintah kedua.

Pada saat merumuskan masalah, subjek melibatkan aktivitas metakognitif planning saat memikirkan dan menuliskan masalah yang dipikirkan; melibatkan aktivitas metakognitif monitoring saat mengecek masalah yang dibuat ketika menyelidiki kebenaran apa yang ditulis dan saat menyelidiki apakah masalah yang dibuat mudah dipahami, yaitu dengan cara membaca kembali masalah yang dibuat; melibatkan aktivitas metakognitif evaluating saat menyelidiki kesesuaian pelaksanaan rencana dalam merumuskan masalah, yaitu dengan cara mengamati kembali masalah yang dibuat. 
Pada saat menyelesaikan masalah, subjek melibatkan aktivitas metakognitif planning saat memikirkan untuk mencoba menyelesaikan masalah yang dibuat; melibatkan aktivitas metakognitif monitoring saat menyelidiki potensi diri dalam menyelesaikan masalah yang dibuat yaitu, dengan merasa kesulitan mencari cara penyelesaian masalah kedua yang dibuat; subjek tidak melibatkan aktivitas metakognitif evaluating pada tahap menyelesaikan masalah yang dibuat.

Pada saat memeriksa kembali, subjek tidak melibatkan aktivitas metakognitif planning dalam memeriksa kembali masalah yang dibuat; melibatkan aktivitas metakognitif monitoring saat mengecek kembali masalah yang dibuat dan perintah kedua ketika menyelidiki kesesuaian masalah yang dibuat dengna informasi awal; melibatkan aktivitas metakognitif evaluating saat memperhatikan kembali masalah yang dibuat ketika meyakinkan pada diri sendiri bahwa masalah yang dibuat sudah sesuai dengan informasi awal; dan saat mengoreksi potensi diri sendiri dalam mengajukan masalah.

\section{Proses Metakognitif Subjek 3 (SIK1)}

Pada subjek SIK1 dalam pengajuan masalah telah menunjukkan proses metakognitif pada aktivitas merencanakan, memantau dan mengevaluasi dalam setiap tahapan pengajuan masalah yaitu AR, AM, AE, BR, BM, BE, CR, CM, CE, DR, DM, DE, ER, EM, dan EE. Alur proses metakognitif dalam pengajuan masalah pada setiap indikator seperti pada Gambar 3.

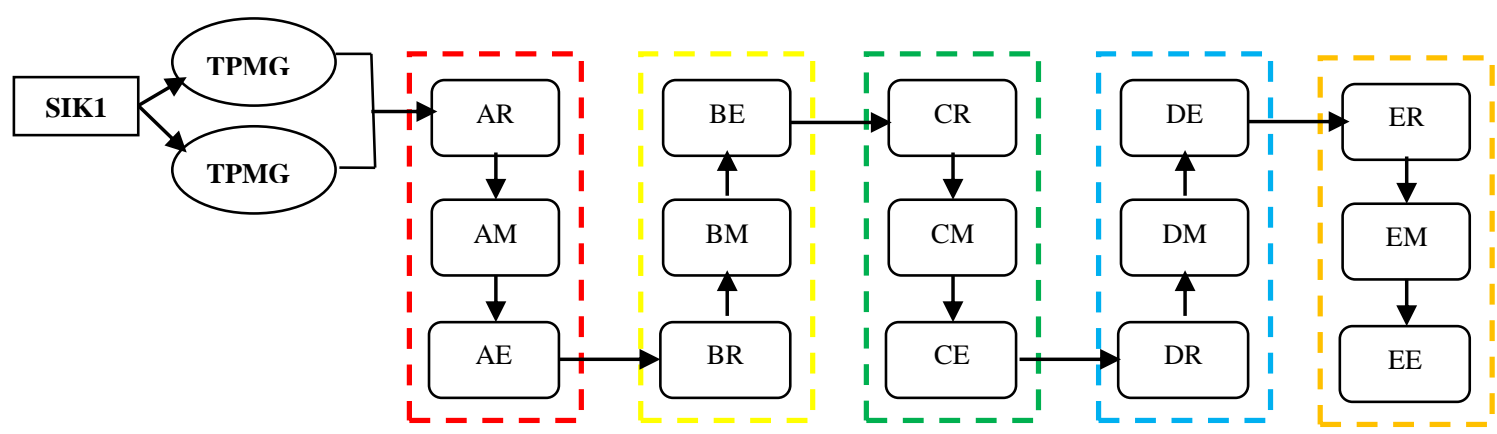

Gambar 3. Proses Metakognitif SIK1

Pada saat memahami informasi, subjek melibatkan aktivitas metakognitif planning saat memikirkan cara memahami informasi dengan cara membaca perintah kedua dan saat memikirkan cara memahami informasi dengan cara mempelajari kembali masalah awal; melibatkan aktivitas metakognitif monitoring saat mengecek pemahaman 
informasi yaitu dengan cara mengungkapkan informasi yang dipahami pada perintah kedua, saat mengecek pemahaman informasi yaitu dengan cara mengungkapkan informasi yang dipahami pada masalah awal dan saat mengetahui adanya informasi lain yang dipahami pada masalah awal yaitu dengan cara memperhatikan kembali masalah awal; melibatkan aktivitas metakognitif evaluating saat memeriksa pemahaman informasi yaitu dilakukan dengan cara memperhatikan kembali perintah kedua, saat memeriksa pemahaman informasi yaitu dilakukan dengan cara memperhatikan kembali masalah awal, saat memeriksa kesesuaian informasi yang diungkapkan dari yang dipahami pada perintah kedua maupun masalah awal dengan cara memperhatikan perintah kedua, dan saat memeriksa kesesuaian informasi yang diungkapkan dari yang dipahami pada perintah kedua maupun masalah awal dengan cara memperhatikan masalah awal.

Pada saat menyusun rencana pengajuan masalah, subjek melibatkan aktivitas metakognitif planning saat memikirkan bentuk bangun ruang pada masalah yang akan dibuat, saat memikirkan pertanyaan pada masalah yang akan dibuat dan saat memikirkan informasi pada perintah kedua yaitu masalah yang akan dibuat harus lebih rumit dari masalah sebelumnya; melibatkan aktivitas metakognitif monitoring saat mengecek apa saja yang harus direncanakan sebelum menyusun masalah, yaitu dengan cara mengungkapkan bangun ruang, ukuran bangun ruang dan pertanyaan yang akan dipakai pada masalah yang akan dibuat; dan saat mengecek ide asal dan alasan akan menggunakan ide tersebut, yaitu dengan cara mengungkapkan ide asal yang dipikirkan dan alasan memikirkan ide tersebut dalam menyusun rencana pengajuan masalah; melibatkan aktivitas metakognitif evaluating saat memeriksa kembali masalah yang sudah dipikirkan, yaitu dilakukan dengan cara memperhatikan kembali oret-oretan ketika memeriksa tingkat kesulitan masalah yang akan dibuat; saat memeriksa kembali masalah yang sudah dipikirkan akan bisa diselesaikan, yaitu dengan menyatakan tidak yakin bahwa masalah yang dipikirkan bisa diselesaikan; dan saat memeriksa kesesuaian rencana dalam menyusun masalah dengan informasi sebelumnya yang diperoleh, yaitu dilakukan dengan cara memperhatikan kembali masalah awal maupun perintah kedua.

Pada saat merumuskan masalah, subjek melibatkan aktivitas metakognitif planning saat memikirkan dan menuliskan masalah yang dipikirkan; melibatkan aktivitas metakognitif monitoring saat mengecek masalah yang dibuat ketika 
menyelidiki kebenaran apa yang ditulis dan saat menyelidiki apakah masalah yang dibuat mudah dipahami, yaitu dengan cara membaca kembali masalah yang dibuat; melibatkan aktivitas metakognitif evaluating saat menyelidiki kesesuaian pelaksanaan rencana dalam merumuskan masalah, yaitu dengan cara mengamati kembali masalah yang dibuat.

Pada saat menyelesaikan masalah, subjek melibatkan aktivitas metakognitif planning saat memikirkan untuk mencoba menyelesaikan masalah yang dibuat dan saat memikirkan dan mengungkapkan langkah dan hasil akhir penyelesaian masalah yang dibuat; melibatkan aktivitas metakognitif monitoring saat menyelidiki kebenaran langkah dan hasil akhir penyelesaian masalah yang dibuat, yaitu dengan cara mengecek kembali langkah dan hasil akhir penyelesaian masalah yang dibuat; melibatkan aktivitas metakognitif evaluating saat menyelidiki kesesuaian pelaksanaan rencana dalam menyelesaikan masalah yang dibuat, yaitu dengan cara mengamati kembali apa yang sudah dikerjakan.

Pada saat memeriksa kembali, subjek melibatkan aktivitas metakognitif planning saat memikirkan untuk memeriksa kembali masalah yang dibuat; dan saat memikirkan dan mengungkapkan apa yang dipikirkan ketika memeriksa kembali kesesuaian masalah yang dibuat dengan informasi awal; melibatkan aktivitas metakognitif monitoring saat mengecek kembali masalah yang dibuat, perintah kedua dan masalah awal ketika menyelidiki kesesuaian masalah yang dibuat dengan informasi awal; melibatkan aktivitas metakognitif evaluating saat memperhatikan kembali masalah yang dibuat ketika meyakinkan pada diri sendiri bahwa masalah yang dibuat sudah sesuai dengan informasi awal dan saat mengoreksi potensi diri sendiri dalam mengajukan masalah.

\section{Proses Metakognitif Subjek 4 (SIK2)}

Pada subjek SDK2 selama pengajuan masalah telah menunjukkan proses metakognitif pada aktivitas merencanakan, memantau dan mengevaluasi dalam tahapan pengajuan masalah, namun tidak melakukan proses metakognitif yang melibatkan aktivitas evaluasi pada tahap menyelesaikan masalah yang dibuat yaitu AR, AM, AE, BR, BM, BE, CR, CM, CE, DR, DM, ER, EM, dan EE. Alur proses metakognitif dalam pengajuan masalah pada setiap indikator seperti pada Gambar 4. 


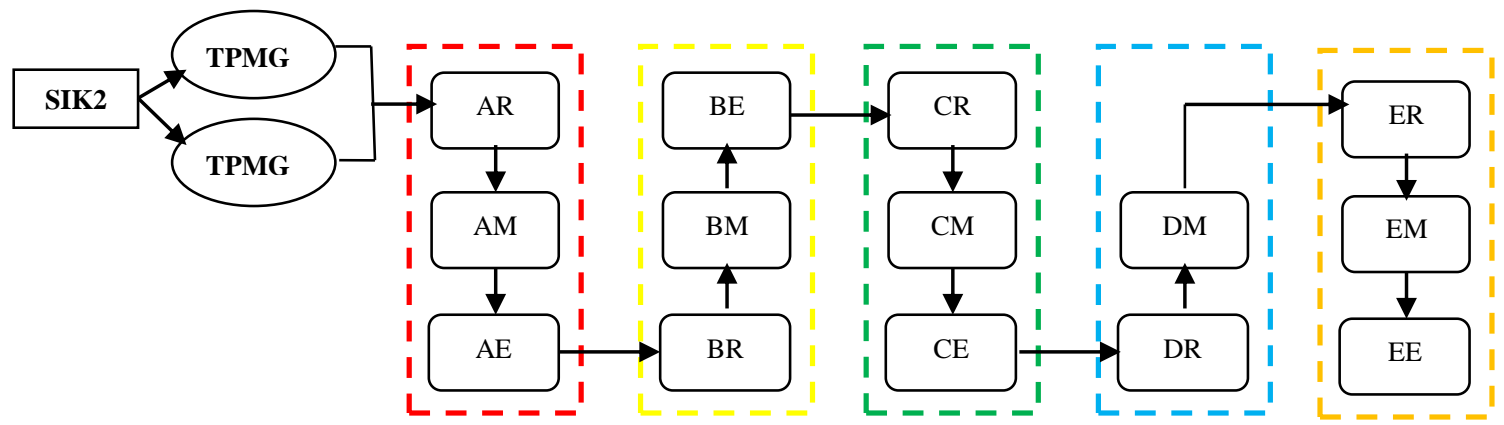

Gambar 4. Proses Metakognitif SIK2

Pada saat memahami informasi, subjek melibatkan aktivitas metakognitif planning saat memikirkan cara memahami informasi yaitu dengan cara membaca perintah kedua; melibatkan aktivitas metakognitif monitoring saat mengecek pemahaman informasi yaitu dengan cara mengungkapkan informasi yang dipahami pada perintah kedua; melibatkan aktivitas metakognitif evaluating saat memeriksa pemahaman informasi yaitu dilakukan dengan cara memperhatikan kembali perintah kedua dan saat memeriksa kesesuaian informasi yang diungkapkan dari yang dipahami pada perintah kedua dengan cara memperhatikan perintah kedua.

Pada saat menyusun rencana pengajuan masalah, subjek melibatkan aktivitas metakognitif planning saat memikirkan bentuk bangun ruang pada masalah yang akan dibuat, saat memikirkan ukuran bangun ruang pada masalah yang akan dibuat, saat memikirkan pertanyaan pada masalah yang akan dibuat; dan saat memikirkan informasi pada perintah kedua yaitu masalah yang akan dibuat harus lebih rumit dari maslah sebelumnya; melibatkan aktivitas metakognitif monitoring saat mengecek apa saja yang harus direncanakan sebelum menyusun masalah, yaitu dengan cara mengungkapkan bangun ruang, ukuran bangun ruang yang akan dipakai pada masalah yang akan dibuat, saat mengecek apa saja yang harus direncanakan sebelum menyusun masalah, yaitu dengan cara mengungkapkan pertanyaan yang akan dipakai pada masalah yang akan dibuat dan saat mengecek ide asal dan alasan akan menggunakan ide tersebut, yaitu dengan cara mengungkapkan ide asal yang dipikirkan dan alasan memikirkan ide tersebut dalam menyusun rencana pengajuan masalah; melibatkan aktivitas metakognitif evaluating saat memeriksa kembali masalah yang sudah dipikirkan, yaitu dilakukan dengan dengan cara memperhatikan gambar kubus pada penyelesaian masalah awal, saat memeriksa kembali masalah yang sudah dipikirkan akan bisa diselesaikan, yaitu 
dengan menyatakan tidak yakin bahwa masalah yang dipikirkan bisa diselesaikan dan saat memeriksa kesesuaian rencana dalam menyusun masalah dengan informasi sebelumnya yang diperoleh, yaitu dilakukan dengan cara memperhatikan kembali masalah awal maupun perintah kedua.

Pada saat merumuskan masalah, subjek melibatkan aktivitas metakognitif planning saat memikirkan dan menuliskan masalah yang dipikirkan; melibatkan aktivitas metakognitif monitoring saat mengecek masalah yang dibuat ketika menyelidiki kebenaran apa yang ditulis; dan saat menyelidiki apakah masalah yang dibuat mudah dipahami, yaitu dengan cara membaca kembali masalah yang dibuat; melibatkan aktivitas metakognitif evaluating saat menyelidiki kesesuaian pelaksanaan rencana dalam merumuskan masalah, yaitu dengan cara mengamati kembali masalah yang dibuat.

Pada saat menyelesaikan masalah, subjek melibatkan aktivitas metakognitif planning saat memikirkan untuk mencoba menyelesaikan masalah yang dituliskan; dan saat memikirkan dan mengungkapkan langkah dan hasil akhir penyelesaian masalah yang dibuat; melibatkan aktivitas metakognitif monitoring saat menyelidiki kebenaran langkah dan hasil akhir penyelesaian masalah yang dibuat, yaitu dengan cara mengecek kembali langkah dan hasil akhir penyelesaian masalah yang dibuat; subjek tidak melibatkan aktivitas metakognitif evaluating pada tahap menyelesaikan masalah yang dibuat.

Pada saat memeriksa kembali, subjek melibatkan aktivitas metakognitif planning saat memikirkan untuk memeriksa kembali masalah yang dibuat; dan saat memikirkan dan mengungkapkan apa yang dipikirkan ketika memeriksa kembali kesesuaian masalah yang dibuat dengan informasi awal; melibatkan aktivitas metakognitif monitoring saat memperhatikan kembali masalah yang dibuat, perintah kedua dan masalah awal ketika menyelidiki kesesuaian masalah yang dibuat dengan informasi awal; melibatkan aktivitas metakognitif evaluating saat memperhatikan kembali masalah yang dibuat ketika meyakinkan pada diri sendiri bahwa masalah yang dibuat sudah sesuai dengan informasi awal dan saat mengoreksi potensi diri sendiri dalam mengajukan masalah.

Adapun temuan dari hasil penelitian ini yaitu ketika menyelesaikan masalah yang dibuat, subjek SDK1 dan SIK1 menggunakan pengetahuan prasyarat seperti rumus phytagoras, kesebangunan dan trigonometri. Hal ini sependapat dengan Gagne, Briggs 
\& Wager (1992) bahwa suatu topik matematika dipelajari bila hirarki prasyaratnya telah dipelajari. Ketika menyusun rencana pengajuan masalah, SDK1 mengungkapkan ide asal rencana masalah yang akan dibuat yaitu berasal dari soal-soal yang pernah ia kerjakan dari buku sekolah. Hal ini sependapat dengan Witkin et al. (1977) bahwa individu dengan gaya kognitif FD bersifat global yaitu mudah dipengaruhi lingkungannya. Ketika menyusun rencana pengajuan masalah, SIK1 mengungkapkan ide asal rencana masalah yang akan dibuat yaitu berasal dari pemikirannya sendiri tanpa mengingat soal-soal yang pernah dikerjakan. Hal ini sependapat dengan Witkin et al. (1977) bahwa individu dengan gaya kognitif FI bersifat analisis yaitu kurang dipengaruhi lingkungannya. Subjek SDK1 menyadari bahwa dengan memikirkan untuk merencanakan bangun ruang, ukuran bangun ruang dan pertanyaan pada masalah yang dipikirkan maka ia merasa yakin akan dapat menyelesaikan masalah yang direncanakan dengan mudah. Hal ini sependapat dengan Desoete (2007) bahwa orientasi keterampilan dalam memprediksi dapat membuat pekerjaan seseorang menjadi lebih cepat bila permasalahannya sudah dikenal.

Selain itu terlihat bahwa meskipun SDK1 dan SDK2 mempunyai gaya kognitif yang sama ternyata proses metakognitifnya berbeda. Hal ini dikarenakan SDK1 mempunyai kemampuan pengajuan masalah maupun penyelesaian masalah lebih baik dibandingkan SDK2. Hal serupa juga ditunjukkan oleh SIK1 dan SIK2. Sedangkan SDK1 dan SIK1 mempunyai gaya kognitif yang berbeda ternyata proses metakognitifnya sama. Dikatakan sama dalam hal ini karena mereka telah melibatkan aktivitas metakognitif dalam merencanakan, memantau, dan mengevaluasi dalam setiap tahapan pengajuan masalah.

\section{SIMPULAN DAN SARAN}

Berdasarkan hasil analisis data di atas, dapat disimpulkan bahwa subjek SDK1 dan SIK2 telah melakukan aktivitas metakognisi dalam merencanakan, memantau dan mengevaluasi proses dan hasil berpikirnya pada setiap tahapan pengajuan masalah sedangkan subjek SDK2 dan SIK2 tidak melakukan aktivitas metakognisi evaluasi dalam menyelesaikan masalah dikarenakan tidak mempunyai cukup pengetahuan dalam menyelesaikan masalah yang dibuat dan subjek SDK2 juga tidak melakukan aktivitas metakognisi dalam merencanakan dalam memeriksa kembali kesesuaian masalah yang 
sudah dibuat dengan informasi sebelumnya.

Berdasarkan hasil penelitian tersebut, dapat disarankan bagi guru agar memperhatikan dan mengembangkan kemampuan metakognitif siswa dalam proses pembelajaran, guna meningkatkan kemampuan pengajuan masalah maupun penyelesaian masalah.

\section{DAFTAR RUJUKAN}

Abdussakir. (2009). Pembelajaran matematika dengan problem posing. Diakses pada 25 Februari 2016, dari https://abdussakir.wordpress.com/2009/02/13/ pembelajaran-matematika-dengan-problem-posing/

Arends, R. I. (1997). Classroom instruction and management. New York: McGraw Hill.

Budiarto, M. T. (2000). Pembelajaran geometri dan berpikir geometri. Prosiding Seminar Nasional Matematika, 2 November 2000. Surabaya: Jurusan Matematika FMIPA ITS Surabaya.

Brown, A. (1987). Metacognition, executive control, self-regulation, and other more mysterious mechanisms. Metacognition, motivation, and understanding, 65-116.

Cai, J., Lane, S., \& Jakabcsin, M. S. (1996). "The role of open-ended tasks and holistic scoring rubrics: Assessing students' mathematical reasoning and communication", dalam Communication in Mathematics, K-12 and Beyond. Virginia: NCTM.

Dawson, T. L. (2008). Metacognition and learning in adulthood. Prepared in response to tasking from ODNI/CHCO/IC Leadership Development Office, Developmental Testing Service, LLC.

Desoete, A. (2007). Evaluating and improving the mathematics teaching-learning process through metacognition. Electronic Journal of Research in Educational Psychology, 5(3), 705-730.

Flavell, J. H. (1979). Metacognitive and cognitive monitoring: A new area of cognitivedevelopmental inquiry. American Psychologist, 34(10), 906-911.

Frenkel, S. (2014). Metacognitive components in learning to learn approaches. International Journal of Psychology: A Biopsychosocial Approach, 14, 95-112.

Gagne, R. M., Briggs, L. J., \& Wager, W. W. (1992). Principles of instructional design. New York: Harcourt Brace Javanovich College Publishers.

Karnain, T., Bakar, M. N., Siamakani, S. Y. M., Mohammadikia, H., \& Candra, M. (2014). Exploring the metacognitive skills of secondary school students' use during problem posing. Sains Humanika, 67(1), 27-32. DOI: $10.11113 /$ sh.v67n1.121 
Kuzle, A. (2011). Pattern of metacognitive behaviour during mathematics problem solving in a dynamic geometry environment. Diakses pada 10 Desember 2015, dari www.jwilson.coe.uga.edu

North Central Regional Educational Laboratory. (1995). Metacognition in strategic teaching and reading project guidebook. Diakses pada 11 Desember 2016, dari http://www.ncrel.org/sdrs/areas/ issues/students/learning/ Ir1metp.htm.

National Council of Teachers of Mathematics. (2007). Principles and standards for school mathematics. Reston, VA: Author.

Resnick, L. B. (1987). Education and learning to think. Washington, D. C: National Academy Press.

Siswono, T. Y. E. (2002). Proses berpikir siswa dalam pengajuan soal. Jurnal Nasional Matematika, Jurnal Matematika atau Pembelajarannya, Tahun VIII ISSN: 08527792, 44-50.

Sudia. (2013). Profil metakognisi siswa yang bergaya kognitif impulsif-reflektif dalam memecahkan masalah terbuka materi geometri ditinjau dari perbedaan jenis kelamin. (Disertasi). UNESA, Surabaya.

Sugiyono. (2011). Metode penelitian kuantitatif kualitatif dan R\&D. Bandung: Alfabeta

Witkin, H. A., Moore, C. A., Goodenough, D. R., \& Cox, P. W. (1975). Field-dependent and field-independent cognitive styles and their educational implications. ETS Research Report Series, 1975(2), 1-64.

Yeap, B. H. (1997). Mathematical problem solving: A focus on metacognition. (Unpublished Dissertation). Nanyang Technological University, Singapore. 